10 - ORIGINAL ARTICLE Genitalia, Female

\title{
The effect of copaiba balsam on Walker 256 carcinoma inoculated into the vagina and uterine cervix of female rats ${ }^{1}$
}

\author{
Efeito do óleo de copaíba no tumor de Walker 256 inoculado em vagina e colo de útero de ratas \\ fêmeas
}

\author{
Nara Macedo Botelho Brito ${ }^{\mathrm{I}}$, Marcus Vinicius Henriques Brito ${ }^{\mathrm{II}}$, Rita de Kássia Vidigal Carvalho ${ }^{\mathrm{II}}$, Lia Tavares de Moura \\ Brasil Matos $^{\mathrm{IV}}$, Rodolfo Costa Lobato ${ }^{\mathrm{IV}}$, Suelen Costa Correa ${ }^{\mathrm{IV}}$, Rosângela Baía Brito ${ }^{\mathrm{V}}$ \\ ${ }^{I} \mathrm{PhD}$, Associate Professor, Department of Specialized Health, UEPA, Pará, Brazil. \\ ${ }^{\text {II }} \mathrm{PhD}$, Associate Professor, Department of Integrated Health, UEPA, Pará, Brazil. \\ III MD, UEPA, Pará, Brazil. \\ ${ }^{\text {IV }}$ Graduate student, UEPA, Pará, Brazil. \\ ${ }^{\vee}$ MD, Pathologist, UEPA, Pará, Brazil.
}

\begin{abstract}
Purpose: To verify the copaiba balsam (Copaifera officinalis) effect on Walker 256 carcinoma inoculated into vagina and uterine cervix of rats. Methods: Eighteen female Wistar rats weighing between 180-250g were used, distributed into 2 groups (GCop, GC). On the 1st day of the experiment, $0.3 \mathrm{ml}$ of Walker 256 carcinoma $\left(2 \times 10^{6}\right.$ concentration) was inoculated in both groups; on the $3 \mathrm{rd}$ day of the experiment, it was given $4.8 \mathrm{ml} / \mathrm{kg}$ of distilled water to the GC group, and $4.8 \mathrm{ml} / \mathrm{kg}$ of copaiba balsam to the GCop group. On the 12th day, euthanasia was performed and the tumor was grafted, being weighted and verified its volume. The data were submitted to statistical analysis with ANOVA test. Results: It was observed that copaiba balsam presented a negative inhibitory potential of $70 \%$. Conclusion: The copaiba balsam stimulated the tumor growth.
\end{abstract}

Key words: Plants, Medicinal. Carcinoma 256, Walker. Uterine Cervical Neoplasms. Rats.

\section{RESUMO}

Objetivo: Verificar o efeito do óleo de copaíba da espécie Copaifera officinalis no carcinoma de Walker 256 inoculado em vagina e colo de útero de ratas. Métodos: Foram utilizadas 18 ratas da linhagem Wistar, pesando entre 180-250g, distribuídas em dois grupos (CCop, GC). No $1^{\circ}$ dia de experimento, em ambos os grupos foi inoculado $0,3 \mathrm{ml}$ de tumor de Walker 256 na concentração de $2 \times 10^{6}$; no $3^{\circ}$ dia após essa inoculação, foi iniciada a administração de água destilada na dose de $4,8 \mathrm{ml} / \mathrm{kg}$ ao $\mathrm{GC}$, e copaíba na dose de $4,8 \mathrm{ml} / \mathrm{kg}$ ao GCop. No $12^{\circ}$ dia foi realizada a eutanásia das ratas e ressecado o tumor, sendo este pesado e averiguado seu volume. Os dados obtidos foram submetidos à análise estatística pelo método ANOVA. Resultados: Observou-se que o óleo de copaíba apresentou um potencial inibitório negativo de 70\%. Conclusão: O óleo de copaíba estimulou o crescimento tumoral.

Descritores: Plantas Medicinais. Carcinoma 256 de Walker. Neoplasias do Colo do Útero. Ratos.

${ }^{1}$ Research performed at the Laboratory of Experimental Surgery, State University of Pará (UEPA), Brazil.

\section{Introduction}

Uterine cervix cancer is the 5th most common cancer among women ${ }^{1}$. In Brazil, it is estimated that uterine cervix cancer is the $3 \mathrm{rd}$ most common malignant neoplasm among women, being surpassed just by skin cancers (non-melanoma) and breast cancer, being the 3 rd cause of death by cancer on women ${ }^{2}$.

Akin to many other types of cancer, if detected early, uterine cervix cancer has a great percentage of cure; however, on further stages, there are few treatment options, based primarily on systemic chemotherapy ${ }^{3}$.

Based on that, cytotoxic and hormonal drugs as well as biological agents have been used on cancer treatment. However, such drugs often have pitfalls, due to the fact they have high toxicity against non-cancerous cells, and also because various types of cancer cells are resistant against therapy. Therefore, development and test of new anti-cancer substances is necessary ${ }^{4}$.

One of the best ways to test novel substances is to use it against experimental tumors. The induction model of Walker 256 carcinoma has been largely described in the literature. However, the only available model of Walker 256 carcinoma in the uterine cervix was described by Brito et al. ${ }^{5}$, which can be used to test novel drugs with anti-tumoral effects.

Among these drugs, there are medicinal plants that have been used for many years for the treatment of various diseases, with an increase of their use during the last decade. Nonetheless, there is little evidence about their toxicity and efficacy ${ }^{6}$.

In Brazil, it is of great importance the use of copaiba 
balsam, especially in the Amazon region. This balsam is attributed to have anti-inflammatory activity, wound healing properties and gastroprotective activity, which have been already confirmed on previous studies ${ }^{7-9}$. On the other hand, there are several other usages credited by Brazilian population, who consider that the balsam have hypotensive characteristics as well as anti-rheumatic, anti-spasmodic, laxative, contraceptive and anti-tumoral properties $^{10}$.

The copaiba balsam is largely used among population for gynecological cancers treatment like vaginal cancer and uterine cervix cancer ${ }^{9}$. Copaiba balsam anti-tumoral activity was previously tested with other species of the oil, like C. langsdorfii, C. reticulata Ducke and C. multijuga, and with other animal carcinoma models. However, C. officinalis action on Walker 256 carcinoma, especially when inoculated into the vagina and uterine cervix, has never been tested. Since there are no studies on that and the number of researches about the anti-tumoral effect of copaiba balsam is low, this study aimed to verify the effect of copaiba balsam (Copaifera officinalis) on Walker 256 carcinoma inoculated into the vagina and uterine cervix of rats.

\section{Methods}

The handling of all animals used during this research was done according to the Brazilian regulations in force for animal vivisection and the norms of the Brazilian College for Animal Experimentation. The Ethical Committee on Research of the State University of Pará approved this experiment. In addition, all animals used in this study received the humane care in compliance with Guide for Care and Use of Laboratory Animal (NIH publication 85-23, revised 1985).

\section{* Substances}

The substances used on this paper were the Copaifera officinalis crude oil (Brasmazon) and distilled water.

\section{* Samples}

Eighteen female Wistar rats weighing 180 - 250g were obtained from Evandro Chagas Institute (Belém - Pará). Animals were kept under standard rodent laboratory housing at conditions with 12 hours day/night cycles and given standard rodent chow diets and tap water ad libitum.

Nine animals were assigned to each group and treated as following:

Control Group (GC): animals treated with $4.8 \mathrm{ml} / \mathrm{kg}$ of distilled water through gavage.

Copaiba Balsam Group (GCop): animals treated with 4.8 $\mathrm{ml} / \mathrm{kg}$ of copaiba balsam through gavage.

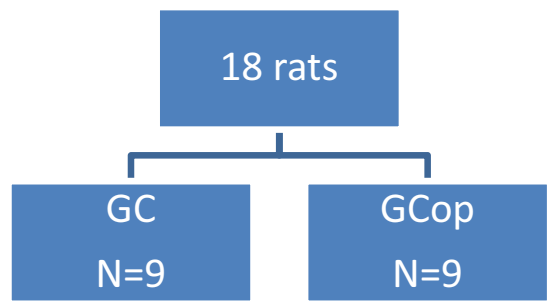

* Procedures

All animals were submitted to inhalatory anesthesia 21 days prior to tumor inoculation, to perform bilateral oophorectomy. After 21 days, vaginal scraping was performed in order to confirm the anestruous.

The day before the tumor cells were inoculated on the assigned groups (day 0), the rats were anaesthetized with diethyl ether and $0.3 \mathrm{ml}$ of acetic acid (10\%) was inoculated into the organ (Figure 1).

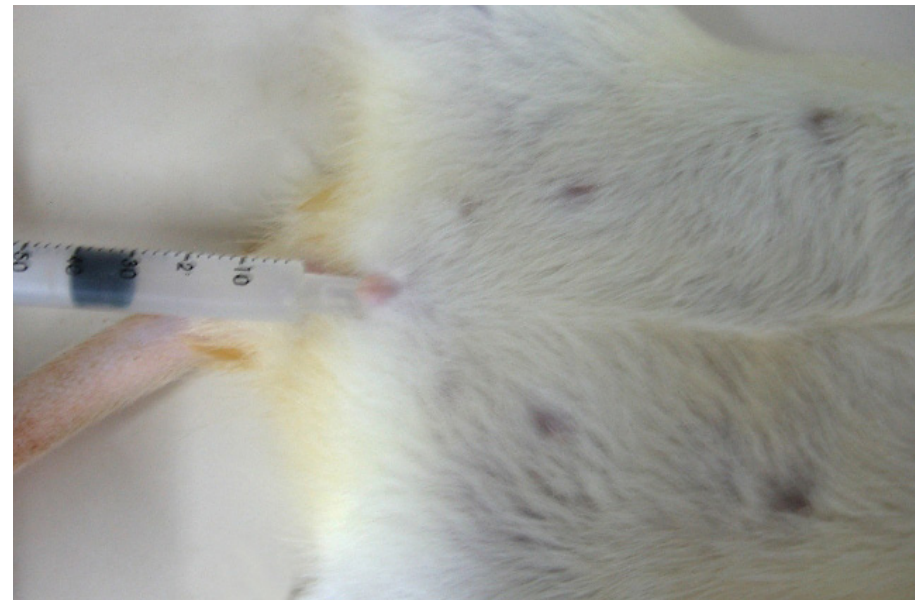

FIGURE $1-10 \%$ acetic acid inoculation

On the day 1 of the experiment, tumor cell inoculation into the vagina and uterine cervix was done under general anesthesia with diethyl ether. An endocervical brush was used to scrape the vaginal wall (Figure 2) and after that $0.3 \mathrm{ml}$ of the liquid containing tumor cells was inoculated into the vagina and uterine cervix. On this day, rats had their initial weights measured and kept for further analysis.

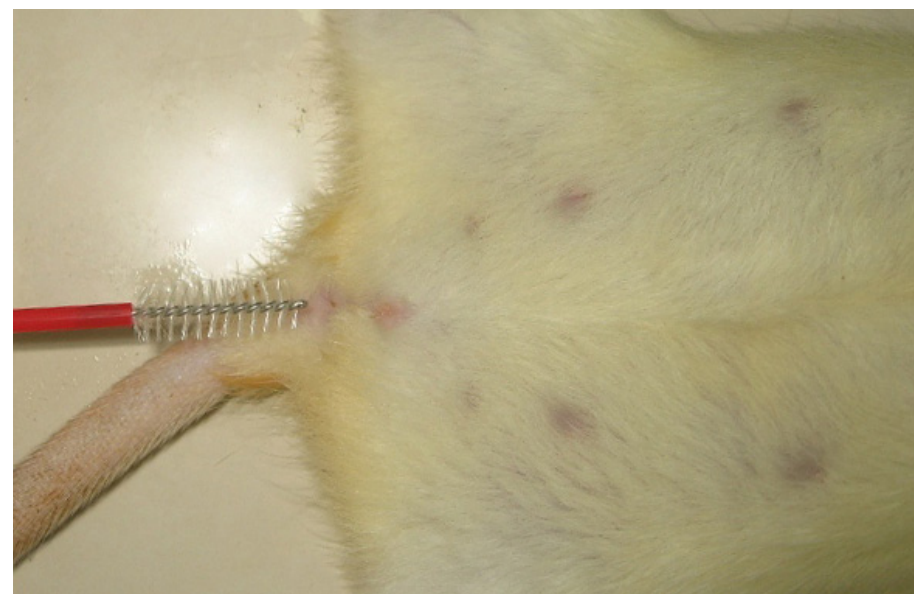

FIGURE 2 - Vaginal scraping

On the 3rd day post tumor inoculation, the treatment with copaiba balsam or water began. Before the gavage, the animals were weighed and the dosage of oil or water was calculated. The assigned drugs were given to each group until the assigned date for euthanasia (until the 11th day). 
For the tumor analysis, animals were euthanized at day 12 following tumor cell implantation by an excessive inhalation of diethyl ether. Before euthanasia, each rat had its final weight taken. After that, a laparotomy was performed in order to analyze the presence of macroscopic metastasis sites and to allow the removal of uterus, vagina, cervix and rectum for further analysis and separation of uterine cervix and vagina.

The tumors were extracted entirely and weighed. They were then sectioned and counter stained with hematoxylin and eosin for histopathologic evaluation.

The average tumor weight of copaiba balsam group was compared to control group average. The results were given by the following equation that expresses potential of inhibition, created by Tarnowisk and Stock $(1957)^{11}$ :

$$
\mathrm{PI}(\%)=1-\frac{\mathrm{Tt} \times 100}{\mathrm{Tc}}
$$

Where ' $\mathrm{Tt}$ ' means the average tumor weight of treatment group (copaiba group) and 'Tc' means the average tumor weight of control group.

The obtained data was analyzed by one-way analysis of variance - ANOVA test. $\mathrm{P}$ values $<0.05$ were taken to indicate statistical significance.

\section{Results}

When evaluated the weight loss between the groups, the one treated with copaiba balsam presented weight loss significantly higher than the one that received distilled water (Figure 3 ).

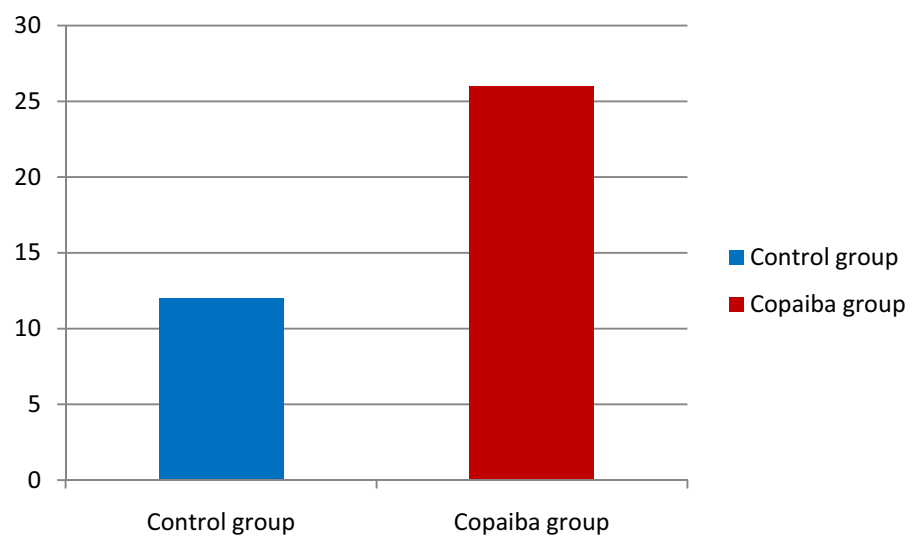

FIGURE 3 - Comparison between weight loss variation in grams between rats of GC and GCop inoculated with Walker 256 carcinoma $* \mathrm{p}<0.05$ (ANOVA)

That can be corroborated when analyzing tumor weight (Table 1). There was statistical difference between the weights, once the tumor weight of copaiba treated group was higher than control group.

TABLE 1 - Tumoral weight of GC and Gcop, in grams

\begin{tabular}{ccc}
\hline & Control Group & Copaiba Balsam Group * \\
\hline R1 & 1.89 & 2.49 \\
R2 & 1.88 & 7 \\
R3 & 2.61 & 6.1 \\
R4 & 2.22 & 6.303 \\
R5 & 5.479 & 4.889 \\
R6 & 1.572 & 4.112 \\
R7 & 2.32 & 2.42 \\
R8 & 1.3 & 1.3 \\
R9 & 2.34 & 2.5 \\
\hline Media & $\mathbf{2 . 4 0 1 2}$ & $\mathbf{4 . 1 2 3 8} *$ \\
Standard Deviation & $\mathbf{1 . 2 2 4 4}$ & $\mathbf{2 . 0 5 2 3}$
\end{tabular}

SOURCE: Research protocol.

$* \mathrm{p}<0.05$ (ANOVA)

In order to evaluate the inhibitory potential of copaiba balsam, the Tarnowisk and Stock (1957) equation was used. This equation expresses the percentage of tumor growth inhibition, and, according to that, the copaiba balsam had a negative inhibitory potential, meaning a stimulus to tumor growth of more than $70 \%$ (Figure 4). 


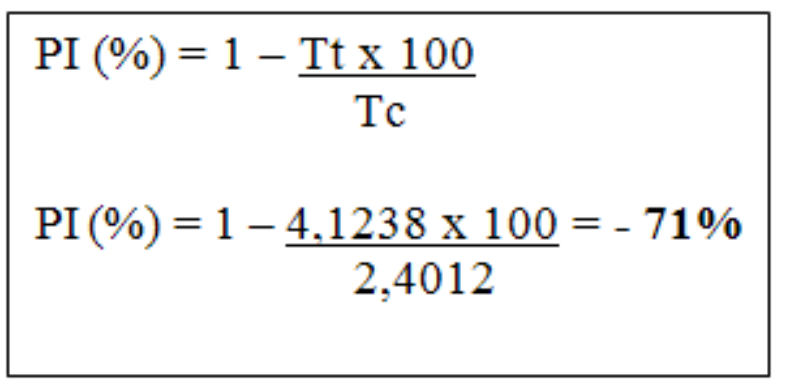

FIGURE 4 - Result of the Tarnowisk and Stock equation applied to this work

\section{Discussion}

Copaiba balsam is commonly described as having similar action to those presented by nonsteroidal anti-inflammatory drugs (NSAIDs) ${ }^{7,12-14}$. On studies performed with naproxen ${ }^{15}$ and celecoxib ${ }^{16}$ there was a decrease on tumor mass and animals maintained their weights during the study. This could be credited to NSAIDs effect on COX-2, therefore inhibiting PGE 2 production ${ }^{17}$, since it hinders tumor cells apoptosis and induces cell proliferation ${ }^{18}$.

On study performed by Lima et al. ${ }^{19}$ copaiba balsam of Copaifera multijuga specie provoked a decrease on tumor growth in vivo of $58 \%$, on a murine melanoma lineage, using a $2 \mathrm{~g} / \mathrm{kg}$ dosage.

Thus, on this study, since it was used a higher dosage of copaiba balsam, the anti-inflammatory and anti-tumoral activities should be increased, causing a great decrease on tumor growth. However, it did not happen, suggesting that copaiba balsam action could be similar to glucocorticoids, since these are used as anti-inflammatory on lower dosages and as immunesuppressants on higher doses ${ }^{20}$.

It is widely known that glucocorticoids induce lymphocyte apoptosis, being useful to treat certain types of neoplasms ${ }^{21}$; nevertheless, it has been shown that glucocorticoids can also inhibit apoptosis on certain tumoral lineage ${ }^{22,23}$ as well as reduce efficacy of chemotherapy on some types of cancer $^{24}$.

So, as long as copaiba oil has a similar action to glucocorticoids, the dosage used in this research could be capable of systemic immunosuppression or inhibition of tumor cells apoptosis, or even both, producing a higher tumoral development.

Thus, it is possible to suggest further studies on pharmacological mechanism of copaiba balsam as well as verify its possible immunosuppressant activity, with specific parameters of immune system evaluation.

\section{Conclusion}

The copaiba balsam on a dosage of $4.8 \mathrm{ml} / \mathrm{kg}$ stimulated Walker 256 carcinoma growth.

\section{References}

1- World Health Organization. Cancer. 2009. [Online]. World Health Organization. Available from http://www.who.int/mediacentre/factsheets/ fs297/en/index.html [accessed 31 May 2009].
2- Instituto Nacional do Câncer, 2008. Estimativa 2008: Incidência de Câncer no Brasil. [Online]. Rio de Janeiro, Brazil: Instituto Nacional do Câncer. Available from http://www.inca.gov/estimativa/2008 [accessed 01 April 2008].

3- Van Luijk IF, Coens C, Van Der Burg ME, Kobierska A, Namer M, Lhomme C, Zola P, Zanetta G, Vermorken JB.Phase II study of bleomycin, vindesine, mitomycin $\mathrm{C}$ and cisplatin (BEMP) in recurrent or disseminated squamous cell carcinoma of the uterine cervix. Ann Oncol. 2007;18(2):275-81.

4- Cannistra SA, Niloff JM. Cancer of the uterine cervix. N Engl J Med. 1996;334(16):1030-7.

5- Brito NMB, Brito MVH, Carvalho RKV, Matos LTMB, Veloso TS, De Vasconcelos DM, Brito RB. Experimental inoculation model of Walker 256 carcinoma into vagina and cervix uteri of female rats. Acta Cir Bras. 2007;22(6):p.495-8.

6- Hu Z, Yang X, Ho PCL, Chan SY, Heng PWS, Chan E, Duan W, Koh HL, Zhou S. Herb-drug interactions: a literature review. Drugs. 2005;65(9):1239-82.

7- Basile, AC, Sertie JA, Freitas PC, Zanini AC. Anti-inflammatory activity of oleoresin from brazilian copaifera. J Ethnopharmacol. 1988;22(1):101-19.

8- Paiva LA, Rao VS, Gramosa NV, Silveira ER. Gastroprotective effect of Copaifera langsdorffii oleo-resin on experimental gastric ulcer models in rats. J Ethnopharmacol. 1998;62(1):73-8.

9- Brito NMB, Kulay JR. L, Simoes MJ, Mora AO, Ramalho LNZ, Novo NF, Juliano Y. Aspectos morfológicos e morfométricos do colo uterino de ratas ooforectomizadas após aplicação de óleo de copaíba. Rev Bras Ginecol Obstet. 2000;22(8):489-93.

10- Souza-Júnior OG, Damous SHB, Lamarão LG. Revisão crítica do uso médico do óleo de copaíba. Rev Para Med. 2000;14(1):71-6.

11- Tarnowski, GS, Stock CC. Effects of combinations of azaserine and 6-diazo-5-oxo-L-norleucine with purine analogs and other antimetabolites on the growth of two mouse mammary carcinomas. Cancer Res. 1957;17(10):1033-9.

12- Veiga-Junior VF, Pinto AC. O gênero Copaifera L. Quim Nova. 2002;25(2):273-86.

13- Veiga VF Jr, Zunino L, Calixto JB, Patitucci ML, Pinto AC. Phytochemical and antioedematogenic studies of commercial copaiba oils available in Brazil. Phytother Res. 2001;15(6):476-80.

14- Gomes NM, Rezende CM, Fontes SP, Matheus ME, Fernandes PD. Antinociceptive activity of Amazonian Copaiba oils. J Ethnopharmacol. 2007;109(3):486-92.

15- Piffar PM, Fernandez R, Tchaikovski O, Hirabara SM, Folador A, Pinto GJ, Jakobi S, Gobbo-Bordon D, Rohn TV, Fabrício VE, Moretto KD, Tosta E, Curi R, Fernandes LC. Naproxen, clenbuterol and insulin administration ameliorates cancer cachexia and reduce tumor growth in Walker 256 tumor-bearing rats. Cancer Lett. 2003;201(2):139-48.

16- Acco A, Da Silva MHRA, Batista MR, Yamamoto NS, Bracht A. Action of celecoxib on hepatic metabolic changes induced by the Walker256 tumour in rats. Basic Clin Pharmacol Toxicol. 2007;101(5):294-300. 17- Schrey, MP, Patel, KV. Prostaglandin E2 production and metabolism in human breast cancer cells and breast fibroblasts. Regulation by inflammatory mediators. Br J Cancer. 1995;72(6):1412-9.

18- Sumitani K, Kamijo R, Toyoshima T, Nakanishi Y, Takizawa K, Hatori M, Nagumo M. Specific inhibition of cyclooxygenase-2 results in inhibition of proliferation of oral cancer cell lines via suppression of prostaglandin E2 production. J Oral Pathol Med. 2001;30(1):41-7.

19- Lima SR, Junior VF, Christo HB, Pinto AC, Fernandes PD. In vivo and in vitro studies on anticancer activity of Copaifera multijuga Hayne and its fractions. Phytother Res. 2003;17(9):1048-105.

20- Wu W, Chaudhuri S, Brickley DR, Pang D, Karrison T, Conzen SD. Microarray analysis reveals glucocorticoid-regulated survival genes that are associated with inhibition of apoptosis in breast epithelial cells. Cancer Res. 2004;64(5):1757-64. 
21- Distelhorst, C.W. Recent insights into the mechanism of glucocorticosteroid-induced apoptosis. Cell Death Differ. 2002;9(1):6-19. 22- Moran TJ, Gray S, Mikosz CA, Conzen SD. The glucocorticoid receptor mediates a survival signal in human mammary epithelial cells. Cancer Res. 2000;60(4):867-72.

23- Schorr, K, Furth PA. Induction of bcl-xL expression in mammary epithelial cells is glucocorticoid-dependent but not signal transducer and activator of transcription 5-dependent. Cancer Res. 2000;60:5950-3.

24- Herr I, Ucur E, Herzer K, Okouoyo S, Ridder R, Krammer PH, von Knebel Doeberitz M, Debatin KM.. Glucocorticoid cotreatment induces apoptosis resistance toward cancer therapy in carcinomas. Cancer Res. 2003;63(12):3112-20.

\section{Correspondence:}

Nara Macedo Botelho Brito

Travessa Padre Eutíquio, 264/1101

66033-000 Belém - PA Brazil

narabrito@amazon.com.br

Conflict of interest: none

Financial source: none

Received: September 17, 2009

Review: November 19, 2009

Accepted: December 16, 2009

\section{How to cite this article}

Brito NMB, Brito MVH, Carvalho RKV, Matos LTMB, Lobato RC, Correa SC, Brito RB. The effect of copaiba balsam on Walker 256 carcinoma inoculated into the vagina and uterine cervix of female rats. Acta Cir Bras. [serial on the Internet] 2010 Mar-Apr;25(2). Available from URL: http://www.scielo.br/acb 